\title{
Extending the Concept of Ethnocracy: Exploring the Debate in the Baltic Context
}

\author{
Timofey Agarin \\ Queen's University Belfast
}

\begin{abstract}
The advance of liberal understanding of democracy with its interest in and constrained ability to interfere with citizens' identities made cases of ethnocracy rare over the past decades. Over the past 25 years, Baltic politics and societies have experienced considerable change, however, as I demonstrate, considerable debate persists around the issues central to the argument about ethnocracy in the region. In the context, when discussing the central role played by state institutions in negotiating conflicts between groups over access to scarce resources of the state, it is central to see minorities as being in both the inferior numerical position as well as in a symbolically more disadvantageous place: If we see democratic politics for what they are as majoritarian politics, and if we see these as taking place in the context of state institutions designed to uphold the ethnic majority dominance, then any kind of liberal democratic politics would be a good candidate for ethnocracy.
\end{abstract}

\section{Introduction}

When James Anderson contacted me to contribute to the debate on ethnocracy in this special issue, I agreed without hesitation. Since my days as a doctoral student I was exposed to discussions on the politics of managing ethnic diversity in what are today Estonia and Latvia. Over the past 25 years, Baltic politics and societies have experienced considerable change; independence from the Soviet Union, a period of post-communist transition, membership negotiations with the European Union, EU accession in 2004, and more than twelve years of membership in both the EU and NATO all have changed the nature of politics in the Baltic states individually and collectively (Agarin 2010; Galbreath 2005). However, as I will demonstrate below, considerable debate persists around the issues central to the argument about ethnocracy in the region.

\footnotetext{
Timofey Agarin, Centre for the Study of Ethnic Conflict, School of History, Anthropology, Philosophy and Politics, Queen's University Belfast. Corresponding author: t.agarin@qub.ac.uk ISSN: 1837-5391; https://epress.lib.uts.edu.au/journals/index.php/mcs CCS Journal is published under the auspices of UTSePress, Sydney, Australia (C) 2016 Timofey Agarin. This is an Open Access article distributed under the terms of the Creative Commons Attribution 4.0 Unported (CC BY 4.0) License (https://creativecommons.org/licenses/by/4.0/), allowing third parties to copy and redistribute the material in any medium or format and to remix, transform, and build upon the material for any purpose, even commercially, provided the original work is properly cited and states its license.
} 
In his opening article James Anderson presents a variegated taxonomy of issues relevant for identifying different types of ethnocracy. However, beyond description of what we find in various places where one ethnic group exercises majoritarian rule over subordinate minorities, we ought to start from the beginning and determine what makes a political regime a candidate for ethnocracy. Nearly all democratic regimes in Europe, East and West, as well as in Asia and Africa, rely heavily on the liberal democratic principle of majoritarian rule. Thus, in countries whose citizenries have a clear ethnic majority we should be presuming a form of ethnocratic dominance of a qualified majority population that determines and facilitates implementation of policies affecting all residents, regardless of their ethnic, cultural, linguistic and religious identities. This would be the case in most countries across the globe.

Such generalisations however would render both the conceptual, and factual contribution that we as students of ethnic politics could make by engaging with debate on ethnocracy futile at best, counterproductive at worst: If nearly all states are ethnocracies, what good is there to single out a select few and analyse relationship between ethnic groups there as being driven by ethnic - rather than any other - issues? Under these circumstances, the question of distinguishing an arithmetic majority of voters who are likely to express more or less similar opinions at the ballot box from patterns of an ethnic majority population acting systematically to undercut interest representation of the remaining, minority populations are essential. Thus, we should look out for cases of discrimination against the resident minority by the numeric majority populations when ethnocratic institutional designs are de jure enshrined in national legislation. The advance of liberal understanding of democracy with its interest in and constrained ability to interfere with citizens' identities made cases of ethnocracy rare over the past decades. This trend, however, seems to go in reverse. As the recent case of the ban on the burkini in France testifies, some states have now began promoting their ethnic identity politics as de facto politics of civic intolerance towards elusively defined minorities (Reuters 2016).

However, although observable in its pure form only in the rarest of instances, ethnocracy is still a useful concept. It allows us to make sense of sets of cases similar in their central features - ethnic diversity of the population at large is constrained by the dominant role of one group in political decision-making, the privileged status of that group vis-à-vis the political institutions of the state, and the culture and language being protected by the state 
which all residents regardless of their ethnic background need to uphold and promote. We can start with Oren Yiftachel's criticism of Sammy Smooha's model of ethnic democracy as an alternative to ethnocracy (Yiftachel 2006). As Anderson rightly points out in his introductory contribution, Yiftachel identifies 'ethnocratic regimes as inherently conflictgenerating'. In these, inequality in access to resources of the states creates an inherently unstable political, but also social environment for co-existence of ethnic groups. It is precisely this lack of political and social stability therefore that makes ethnocratic regimes more and more committed to upholding the dominant position of one group over all others in order to provide a mirror-image of stability generating more, not less, intergroup tensions. Both ethnocracy and ethnic democracy however have been widely used in the scholarship and related to politics in various regions of the world, not least to cases of Estonia and Latvia which I use here as critical references for the discussion in this Special Issue of the Cosmopolitan Civil Societies Journal.

Ethnic diversity has a long history in Estonia, Latvia and Lithuania, yet contemporary state institutions are entrusted to protect identities and interests of ethnic core nations, rather than of all residents. The official narrative of statehood in the Baltic states emphasizes the principle of state continuity from pre-Soviet republics to the present. In so doing, it entrenches inequality between the majority, titular ethnics and the small groups of 'historical minorities', and those who settled in the country during the latter half of the twentieth century, the 'Russian-speaking minorities'. It is at the expense of these large groups of minorities that states have been reformed as democracies for members of the titular majority nation. As such, Estonia and Latvia (alongside Lithuania) have been acknowledged as a fit and welcome addition to the European family of nation-states when Baltic states joined the EU in 2004. Regrettably, only little progress has been made to accommodate the previously excluded groups in Estonia's and Latvia’s societies: In the discussion that follows I will demonstrate that both Estonia and Latvia turned out to be procrustean states instrumentalising the insecurities of majorities to marginalise minority communities’ participation and representation rather than as was previously believed ethnocratic polities on the stable transitory pathway towards a fully fledged democracy. 
Danes and Swedes first, and then German, Jewish and Polish communities have played an important role in the Baltic histories in the past, yielding crucial power over domestic populations and enriching cultural life in the region. Yet, contemporary Baltic societies mainly face challenges of ethnocultural diversity resulting from the Soviet period in the Baltic history. Today, the overwhelming majority of minority groups in the Baltic states speak Russian as their first language (see Table 1). While in everyday life we can fairly easily identify minority from the majority representatives, for the purposes of analyses it is rather difficult to come up with a conceptual definition of what makes minorities in the region candidates for the study as objects of ethnocratic rule

\begin{tabular}{|l|l|l|l|}
\hline & Estonia (03/2014) & Latvia (01/2014) & Lithuania (2011) \\
\hline Total population & $1,352,399$ & $2,180,442$ & $3,043,400$ \\
\hline Majority nation & 898,845 or $69.87 \%$ & $1,299,368$ or $59.6 \%$ & $2,561,300$ or $84.1 \%$ \\
\hline Russians & $25.22 \%$ & $26.9 \%$ & $5.8 \%$ \\
\hline Ukrainians & $1.74 \%$ & $2,4 \%$ & n.a \\
\hline Belarusians & $0.95 \%$ & $3,4 \%$ & $1.2 \%$ \\
\hline Poles & n.a. & $2.2 \%$ & $6.6 \%$ \\
\hline
\end{tabular}

Table 1: Ethnic composition of Baltic States (author's calculation from official statistical data for each country). For details see, Agarin 2016.

In his assessment of interethnic relations in Estonia, Priit Järve has asked questions that are still relevant today, though rarely discussed explicitly: Are Baltic states ethnic democracies? Can post-communist Baltic states be considered hotbeds of ethnic nationalism? Have political institutions failed to put societies on the pathway toward liberal democracy? (Järve 2000). Most of these questions are as topical today as they were 16 years ago and it is wholly insufficient to identify that Estonia, and for that matter also Latvia, is an ethnic democracy. There are indeed several parallels that Järve et al. have identified in their comparative assessment of the situation in Israel and these two Baltic states:

(1) ethnonationalism preceded the establishment of the nation-state after the World War I in both Estonia and Latvia;

(2) majority ethnic nations have had a dominant role in statecraft during the interwar period of statehood, de jure also during the period of Soviet inclusion, and de facto after the independence in 1991;

(3) dominant groups perceive an acute threat from the minority and their external though self-designated - homeland to be the penultimate challenge to majority led nation-state building project; and finally, 
(4) the dominant ethnic group have been committed to some form of democratic decision-making for in-group members albeit at the exclusion of minority groups (Smooha and Järve 2005, 30).

For that reason, it is disingenuous - beside the reason I have set out from, i.e. that most democratic states operating democratically require a majoritarian decision-making to be in place - to infer that politics where we see ethnic dominance are not democratic as such.

Much more, it appears, liberal democracies require a robust set of political institutions to be in place and operational. These require a set of functional criteria to perform successfully on the entire territory of the polity, in just a selected (set of) language(s), promote allegiance of residents to state institutions, and allow participation in political process for those affected. All these criteria can be easily found in states across the globe, be it Australia or Austria, India or Ireland, UK or US, all states committing to protection of individual liberal rights of their citizens could well be veritable candidates for ethnic democracies of sorts. We however need to acknowledge that 'liberal democracy' sensu strictu additionally accords resident minority groups some collective rights, either by means of affirmative action programmes (as in the US), liberal multicultural policies (as in the UK), minority rights (as in Germany), language rights (as in Poland for regional languages), or territorial forms of minority as majority rule (as in Canada for the First Nations on 'their' territories). All of this makes 'ethnic democracy' increasingly indistinguishable from the liberal multicultural democratic approach of building institutions with variegated impact on groups of non-core ethnic communities among the citizenry. Indeed, while most (Western liberal) democratic states have been hailed as having successfully managed their ethnic diversity by facilitating participation and representation of non-dominant societal groups via parallel institutions serving those minority groups exclusively, there is a good chance that such states should also be considered candidates for ethnocratic regimes of scale.

If for no other reason then, ethnic democracy is a type of governance that is inherently democratic in design for some of its members (usually ethnic majority), while implicitly excluding the other members (usually ethnic minority) from participation in political process. This is because despite the fact that institutions of the state are not ethnoculturally defined, functionally the plain upon which visibility, participation, and representation take place are 
tainted by the cultural aspirations of the majority and preclude minority agenda setting on their own terms (McGarry and Agarin 2014; for a more general discussion, see Phillips 2007). Remarkably, therefore, the state which can deliver on its promise to the dominant group must itself commit to several actors: to the international community as an active and viable state on its own right (Cordell 1999), to publics as being a credible ‘service station’ for citizens (Budryte 2005), to domestic political elites to allow unfettered and constitutionally consequential decision-making (Galbreath 2005) and to the majority population as such as a guarantor of its continuous survival in an uncertain international environment (Ehin and Berg 2013).

It is from this perspective that my own past work has echoed much of Yiftachel's criticism of ethnic democracy model (Agarin 2015; Agarin 2010; Agarin 2005): it assumes that states can be formally democratic even though their policies are designed to exclude segments of population on the basis of purported identity claims of state-builders (Yiftachel 2006). This is an important caveat for students of European polities, all of which have been built upon the two contradictory principles: liberal democracy for all citizens and ethnic definition of the state institutions serving primarily the dominant ethnic majority (Agarin 2014; Agarin and Cordell 2016). Indeed some critics have suggested that particularly the new and reconstituted states in the eastern part of Europe have been adamant when enforcing the principles of majority rule, have circumvented consociational arrangements of formal and effective representation of minorities in official political process, as well as undermined guarantees for emergence of group-based solidarity outside the ethnically defined criteria (Jackson-Preece 1997). Yet, after the EU accession of many post-communist states with their political institutions largely unchanged and with the European Union rubber stamping nation-states of majority as having the duty to serve all residents, we could rightly claim that all European, including the EU member-states, are ethnocracies albeit of different form and disguise.

Baltic states provide an excellent point for illustration in this context. After their independence from the Soviet Union in 1991 the majority, state-nations of Lithuania, Latvia and Estonia claimed to be outposts of Western values and opposing the East, in particular Russia. Fifteen years on, EU-accession, rising standards of living and an increasingly Western outlook within the Baltic societies might suggest that they are on their way to catching-up with their European neighbours when it comes to respect and promotion of 
societal diversity. However, popular discontent with political, economic and social reforms appears to be ubiquitous with the legacies of the Soviet past said to present a major impediment to greater successes. In the past, the Estonian and Latvian publics, press and politicians had been persistent in suggesting that the problems encountered during their transition to independent states resulted from the differences in opinions of majority and minority publics on the core issues of post-Soviet development. In fact, the public eye turns most often to the legacies of the Soviet industrialization policies which resulted in the migration of citizens from other Soviet republics into the region (Mertelsmann 2003). However, Soviet nationalities policies promoted the identities of 'titular' groups, recognized their right to national territory and forged a shared civic identity of all residents as a part of the Soviet peoples’ brotherhood (Hajda and Beissinger 1990; G. Smith 1996). For both the majority titular nations and the Soviet-era migrants, provisions for education in their native language were made to foster loyalty to the Soviet state. During the Soviet economic and political reforms of the late 1980s, Baltic nations began to mobilize on ethnopolitical platforms to seek their republics' independence from the Soviet Union, and this was formally achieved in August 1991.

And so, the official narrative of statehood across the Baltic states emphasizes the principle of state continuity from the original, pre-Soviet republics to the present, entrusting states to protect their ethnic core nations. This effectively entrenched inequality between the majority titular ethnics and the small groups of 'historical minorities', and those who settled in the country during the latter half of the twentieth century. Political elites in the Baltic States have consistently emphasized that their states did not join the Soviet Union voluntarily but were unjustly occupied in 1940 and again in 1944, after the German retreat from the area. All three states, therefore, followed the principle of state restitution when re-creating their legal citizenship frameworks as independent states (Van Elsuwege 2008). This principle substantially affected the political rights of minority, non-titular, residents in Estonia and Latvia.

In post-Soviet Estonia and Latvia, only citizens of the pre-war republics and their descendants were entitled to automatic citizenship. In Estonia, only citizens were allowed to vote in the first post-Soviet elections in 1992. As 99.6\% of the citizenry declared themselves to be ethnic Estonians, minorities were not represented in the constituent parliament. Since 
the 1995 general elections, minority representatives have been running on minority party lists or for other parties. Minority parties (including the Constitutional Democratic Party, and the Russian Party of Estonia) were represented in two consecutive parliaments from 1995 to 2003, but since then have failed to collect sufficient votes to enter parliament. Non-citizens can elect and be elected at both municipal and regional elections after a five-year residency period. Owing to their concentrated settlement, minorities have been continuously represented in regional and municipal administrations across northeast Estonia and areas of Tallinn with large Russian-speaking populations. To some extent this regional dominance of Russian-speaking populations has allowed them to send political representatives into municipal councils and administrations to look after their interests better. However, as the overall political process is dominated by Estonian speakers and is geared toward the majority dominance, none of the qualified observers of Estonia's politics has been able to identify a shift toward more minority accommodation even in these regions dominated by Russianspeaking electorates (Nakai 2014; Cianetti 2015).

In Latvia, non-citizens are not allowed to vote in either national or municipal elections. Only citizens of the pre-Soviet Latvian state were allowed to vote in the first post-Soviet elections in 1993; unlike in Estonia, these included small numbers of minority citizens. Although over the years naturalization of Russian-speakers has considerably increased their share among the electorate, there was only a slight rise in numbers of Russian-speaking political actors in Latvia, most running on a minority party list (For Human Rights in United Latvia) or an interethnic party (Harmony Centre). The share of Russian-speakers among political elites is significantly lower than their share among the national electorate. This is due to the fact that all individuals running in national, regional and municipal elections in Latvia must demonstrate the highest level of Latvian language skills. Most political parties representing the Latvian majority continue to press for restrictions on minority participation in politics, primarily by advocating stricter language requirements, though others including the party National Alliance seek to end the naturalization process. National radical organizations also frequently express support for the ‘decolonization’ of Latvia by outlawing Russian-speaking political representatives, stripping Russian-speakers of electoral rights, and deporting Sovietera migrants, including those who have successfully naturalized since 1995. Indeed, this ethnocentric rhetoric focussing, even abusing the perception of the dominant majority about survival of the national, cultural and linguistic community is clearly indicating that at least 
one part of electorate in Latvia is considering ethnocracy in 'their' state a serious option. If the agenda of the National Alliance and its predecessor party For Fatherland and Freedom have for years sought to establish the Latvian state as a state for ethnic Latvian members of the citizenry only, we should certainly identify Latvia's political institutions as ethnically biased and imposing the values, aspirations and not least the language of its majority upon resident minorities as a tool of ethnic control and domination akin to what Yiftachel identifies as ‘ethnocracy’.

The Estonian citizenship law (passed in 1992), and the Latvian equivalent (passed in 1995) made around thirty per cent of residents in Estonia (as 'aliens') and around forty percent in Latvia (as 'non-citizens') de jure stateless, only allowing acquisition of national citizenship through naturalization, despite the fact that most of them were long-term local residents, with an average 20 years' residence, as of 1995. Naturalization procedures require the applicant to successfully sit an exam testing knowledge of the constitution, history, and the national anthem; to swear an oath of allegiance to the state; and, foremost, to pass an examination testing proficiency in the national language. Since 1998, children born to stateless persons in Estonia and Latvia can receive citizenship without this naturalization procedure if their parents apply on their behalf. After peaking in the late 1990s, naturalization rates have since fallen dramatically. In 2008, 932 individuals received Estonian citizenship, while around the same number opted for Russian Federation citizenship. The numbers of individuals who have successfully naturalized in both states have for the first time exceeded the numbers of those still stateless in 2009. On January 1 2014, Latvia’s Population Register counted 295,122 'non-citizens' living in Latvia (approx.14.25\% of residents), down from approximately 715,000 in 1991. On February 1 2014, there were approx. 83,600 ‘aliens’ in Estonia (approx. $6.5 \%$ of residents). All 'aliens' and 'non-citizens' are Russian-speakers, the overwhelming majority declaring themselves to be ethnic Russians. Overall, around 1.64\% of Latvia's and around 7.25\% of Estonia's residents carried Russian Federation passports on January 12014 (Agarin 2016).

Until today, perceptions of social stability in both Latvia and Estonia are woven together with a narrative of (ethno-) national survival. On the other hand, however, one observes the longterm impact of gradual, yet decisive developments in domestic policies of integration put into place as a result of the EU accession pressures: For example, Estonia’s Law on Citizenship 
was amended in 1999 allowing children born after 1992 to parents who are non-citizens to forego the full naturalisation process (Pettai 2005). Also, Estonia's social integration programmes were introduced first in 2000 easing the way of resident non-Estonian noncitizens into an Estonian-dominated public sphere; of late, language tests for citizenship applicants have been simplified in February 2015, facilitating access to Estonian citizenship for the elderly.

The high tensions, intensity of deep distrust and mutual recriminations between Baltic majority titular nationals and Russian- as well as Polish-speakers will require a sustained, sensitive and systematic approach to fostering good neighbourliness and greater cooperation among ethnic communities in the Baltic states (Kochenov and Dimitrovs 2013). The Russian Federation, as successor state of the Soviet Union, claiming to be the ethnic kin state of Russian-speakers in the Baltic states since 1991, can easily be seen as a challenge to regional stability (Agarin 2015). Beside the fact that permanent de jure statelessness of a significant proportion of the population is a strain on the political representation of stateless long-term residents in the two countries, not only the formal representation in political process but much more fundamentally, visibility in the public space are themselves an issue. The status and visibility of 'foreign languages' - de facto all except the state Estonian and Latvian languages respectively - has caused outrage among Russian-speakers and are central to contemporary ethnopolitical tensions (Galbreath and Galvin 2005; Silova 2006).

Governments of both states initiated state language teaching programmes for Russianspeakers as a gateway to citizenship in late 1990s-early 2000s, largely in response to pressures from the High Commissioner on National Minorities prior to the states' NATO accession in 2004 (Kruusvall 2002; Antane and Tsilevich 1999). Yet, insufficient funding, and the lack of qualified personnel, as well as the institutionalized dominance of the state languages and the requirement of language proficiency for naturalization have combined to leave many Russian-speakers in a socially marginal position even after EU accession (Brosig 2008; Muiznieks 2010). In addition, many international initiatives were neutralized by tightened legislation concerning state language use ahead of Latvia's and Estonia's accession to the EU in May 2004 (Mikkel and Pridham 2005). Some observers see ethnopolitical affairs as being in a state of flux in both Estonia and Latvia and stress emphatically the crucial role played by the EU wielding its soft power over these states' nationalising politics (See 
particularly, D. J. Smith 2002). However, tensions around the rights and status of Russian speaking populations have prevented even the recognition of this group in its status as minority over the past two decades.

In Latvia, tensions around the use of the Russian language culminated in a referendum to grant Russian the status of second state language in 2012 (Ijabs 2016; Hanovs 2016). While Latvian-speakers have interpreted the referendum as a challenge to their ethnic group's sovereignty over the state institutions, Russian-speakers rallied around greater political representation of Russian-speakers and inclusion into dialogue about political and social issues at the national level. Though Russian-speakers have succeeded in collecting sufficient signatures for the referendum to be organised by and sponsored by the state, support from the Russian-speaking politicians has been meagre: Support for the referendum was seen by the Latvian political establishment and by the majority, state-bearing nation of the country as a clear sign of disloyalty to the state and has only further reinforced ethnic cleavage. This allowed for the Latvian side of those who were eligible to cast their vote in the referendum to portray the initiative as an 'existential issue' (Ijabs 2016, 299). The was later used by opportunistic (majority) political elites to justify an addition to the Latvian Constitution of a Preamble designating ethnic Latvians as the sole bearers not only of the statehood but also of democracy in the country, the change that was made into law on June 192014.

Overall, the lack of political representation of Russian-speakers continues to undermine their capacity to communicate specific expectations in political forums and be considered viable contributors to developing social institutions of the state. As a result, voting still takes place mostly along ethnic lines, and the crisis in Ukraine has complicated majority-minority relations even further. In Estonia, the participation of Russian-speakers in political and civic life remains very low, and there is a noticeable ethnic segmentation in the labour market in both countries. Furthermore, both states have experienced significant out-migration after joining the EU, which further exacerbates fears of ethnic majority survival and insecurity about national sovereignty (Duina and Miani 2015; Petsinis 2016). Some authors point to the fragmentation of Latvia’s and Estonia’s Russian speaking communities alongside socioeconomic markers to emphasise the potential for greater interethnic interactions in the everyday (Vetik and Helemäe 2011). If nothing else however, these only further limit access 
to scarce resources of the state by the select elites of ethnic majority and those of the co-opted minority, in fact hampering the long-term democratisation of these countries.

Thus it is fair to conclude that the processes of nation-state building for the ethnic majority has impacted on majority-minority relations in both countries significantly and over the decades since independence additionally put the strain on development of political culture that is tolerant of, if not endorsing the dissent and criticism of public policy and decisions made by the elites. It is therefore plain and clear that the stalemate in majority/minority relations observed in Estonia and Latvia today is a product of, rather than a condition for, ethnonational state building. At the heart of this conclusion lays the notion of the nation-state with a clearly defined national majority, whom that state is to serve above all other groups, whose language is a state language and whose culture and history the state is to protect and promote to all residents regardless of their ethnic identities.

Similar to the claim of an ethnocratic nature of the state that both Yiftachel and Smooha make, and Anderson endorses in his introduction, is the idea of political institutions serving primarily the majority and delivering democratic governance for the majority group at an expense of minority communities, regardless of their demographic, economic and political clout. In her Minority Rights in Europe (2005), Tove Malloy suggested that European states whose constituent nation finds itself in a precarious position of majority often opt for nationalising policies vis-à-vis their resident minorities and in doing so invite minority resistance, the involvement of external kin states of the minority, and frequently also international organisations' keen interest in preventing ethnically based conflicts (Petsinis 2016; Herd and Lofgren 2001).

Though in principle this assessment is correct, I beg to differ. The impact minority group representation in ethnically divided societies can have on political opportunities for participation can be easily observed in the Baltic states. Here, we see minorities bringing forward their own concerns to challenge the state-driven decision-making and making clear that they mobilise as groups along the ethnic lines in the first instance to achieve representation of their interest in the public domain as groups but merely to have an access to and be able to participate in state-wide political process as individuals on their own agendas 
(Agarin 2013). This notion however is particularly challenging to the dominant mode of decision-making in contemporary liberal democracies which often do more than question the minority benevolence in challenging policies and institutions of the state as such. By inviting minority representatives into the ranks of the majority-dominated political elites, they undercut minority representation in terms that are particularly relevant for the group itself and usher in reframing of their interests in terms suitable for the ethnic, state-bearing majority. And it is precisely because minority representatives find no space for their (ethnic, cultural, religious, linguistic, etc) identities in the context of political institutions of Latvian and Estonian statehood, that they seek participation in politics in areas that have been previously parcelled out for the majority and have not been reclaimed in totality by the members of majority proper. These succinct and subtle processes of minority co-optation (Agarin 2009), assimilation presented as integration (Malloy 2009) and advocating equality in the public domain for citizens rather for the (institutionally excluded) minority ethnics (Purs 2012) are indicative of the type of governance Yitfachel labels ‘ethnocracy’.

This is where we are coming full-circle in thinking about democratic governance for and by the ethnic majority of the state: Any form of the rule of law installed for and promoted by the majority can easily go down the ethnocratic slope unless credible commitment for domestic publics is in place to keep the ethnonational foundations of governance in check when participating in decision-making. While we are examining political decision-making as a process aimed at a domestic audience and delivering domestic policy outputs, inevitably a lot of other factors are likely to pop up in discussions. In the case of the Baltic states, questions of loyalty of Russian-speakers towards their 'external homeland' have been particularly central to further consolidating domestic ethnocratic governance mechanisms, despite the fact that few (if any) Russian-speakers indicate that their connection to Russia trumps their affiliation with their states of residence (Birka 2016; Demuth 2000; Dorodnova 2000). On the other hand, issues of prejudice against external - and as such unpredictable - actors (with their belligerent rhetoric, as well as their presumed meddling in domestic affairs) open space for wishful thinking where rational analysis should have triumphed. Neither helps us understanding when, and crucially why, ethnocratic governance prevails and is getting entrenched in public opinions and later, via the ballot box in public institutions, becoming the only game in town. 
In conclusion of my brief excursion into the contemporary Baltic region, I can only reiterate my impression that an ethnocratic mode of governance is still the order of the day in both Estonia and Latvia. Though views on the effects of ethnocracy diverge considerably among the members of the majority and minority populations in these countries, these differences can be alarming only in so far as they are representative of the mode of governance across much of the EU today. During the period of Eastern enlargement, the EU had an opportunity to challenge and change domestic institutions delivering governance to the people in all candidate countries. Yet, 12 years since the accession of the then eight post-communist states to the Union when we ought to see European commitment to delivering an inclusive and democratic governance we find it is applied only to people already defined in domestic legislations as prime beneficiaries of state building. In the past, external observers largely overestimated the ability of the EU to challenge legal frameworks, including policies regulating access to citizenship and minority protection in the Baltic region, and across much of the accession states. Today more so than ever the analysis converges on the view that the EU accession process, including conditionality mechanisms sought to, and has, strengthened the institutions of nation-state along the initial pledge to protect and support the numeric (and alas, ethnic) majorities. For one part this is due to the EU's own commitment to majoritarian decision-making, for another, it reflects the focus of supranational politics on the nation-state whose sovereignty has to be taken seriously (Agarin and Cordell 2016; cf. Keating 2004).

Therefore, regardless of my personal unease (which I share deeply with James Anderson) about the persistent nature of ethnocratic governance, there is little room in contemporary international politics to challenge the notion of sovereignty facilitating, if not outright inviting, the forms of democracy that cater to the majority ethnic group among the citizenry. The framework of analysis requiring our attention to ethnocracy as a form of domestic governance presupposed the secondary role of external actors in domestic process. As such, however much we would like to engage with the role both the EU and for that matter, also of Russian Federation as a self-style ethnic homeland of (at least some) Russian-speakers in the Baltic states, these are but external to domestic policymaking on the Baltic region. The fact that each state has been created to serve its own citizens who can - and do - vote on whatever issue they perceive relevant for themselves and elect politicians they choose, makes the choices of demos to maintain ethnocratic regime a narrow-gauge, domestic issue. However much both the 'external homelands' of minorities, or any international organisations 
including the EU and/or NATO might be concerned about the implications of domestic instability resultant from the ethnocratic rule, there is little they can do - without powerful leverage in the form of either positive or negative incentives - to dissuade domestic political entrepreneurs from exploiting the opportunities for further consolidation of ethnocratic governance.

Specifically, this has been happening when the Russian Federation has been portraying itself as a defender of Russian-speakers' interests in the region; factually however, it has been powerless to improve the perceptions, status, and rights of Russian-speaking minorities in either Latvia, or Estonia for 25 years. So whereas publics are welcome to think that there exists some external tool to pressure for and revise ethnocratic governance and policies to endorse minority groups participation in domestic policymaking, no serious academic should take the rhetoric of external actors to be anything else than futile rhetoric.

Where we should start therefore is at the concept of 'ethnocracy' as a tool for analysing processes of governance in ethnically diverse societies. Indeed, when political scientists focus on the state as a set of political institutions which shape the everyday lives of state residents, we ought to question not their origins or their very existence, but the rationale for their change. Ultimately, all political institutions are little more that the sets of rules established by means of social contract in the context of the already existing social institutions and as such, and only as such, do they acquire acceptance and legitimacy from the publics they govern. In the majority of cases, state political institutions are 'out there' to deliver services to taxpayers and citizens expecting something in return, not least the ability of the state to cooperate with its stakeholders. To do so effectively, institutions of the state designate a language in which they can do so most effectively and lay out sets of rules and regulations that (most often) implicitly establish the hierarchy of ethnic groups in their access to state resources.

The newly (re-)established states like Estonia and Latvia are no different from cases of other 'historically evolved' states such as France or Germany in their primary commitment to deliver effective services to their resident populace. Though we are likely to take the ethnicised nature of those historically evolved nation-states for granted, they too at some point in the historic past have 'chosen' an official language, ethnocultural core nation, and 
identified resources to be available for all speakers of 'the' language, but from which others, non-citizens and non-residents, were to be excluded unless these chose to compete on equal terms. In other words, the access to critical positions in and influence on state development has been reserved to individuals with distinct, predefined characteristics of the majority stock by all states, democratic or not, while presuming that others, usually the members of an ethnic minority, were excluded from equal opportunities at least at some point in the historic past.

My fundamental point is that regardless of their political institutional design, democratic or otherwise, liberal or corporatist, all political landscapes are ethnicised to a degree requiring individuals of minority backgrounds to accept rules of the game established by the majority population in order to join in and compete with the majority. Since the collapse of communism however, most Western liberal democracies went to great lengths in facilitating minority participation on their own terms, yet none has achieved complete parity between majority and minority groups in public sphere. This I believe throws the light on what Yitfatchel has been particularly adamant about in his narrower studies (Yiftachel 1998) when talking about the ability of stakeholders to hamper change in institutions and as such in the form of governance.

There are some additional lessons to learn from this also, on the limited ability of the actors excluded from decision-making to impact the 'direction of travel' in domestic politics whose outcomes those excluded might be extremely unhappy about. The lack of progress on accommodation of the cultural, social, economic and political rights of minority, non-titular, communities in Estonia and Latvia should be alarming to NATO and EU member-states. Arrangements to recognise the connection of minority groups to post-Soviet states of residence, rather than to their (however tentative) ethnic kin-state should move onto the political agenda particularly following the recent developments in Ukraine as elsewhere in the post-Soviet region. However, when discussing the central role played by state institutions in negotiating conflicts between groups over access to scarce resources of the state, it is central to see minorities as being in both the inferior numerical position as well as in a symbolically more disadvantageous place: If we see democratic politics for what they are as majoritarian politics, and if we see these as taking place in the context of state institutions 
designed to uphold the ethnic majority dominance, then any kind of liberal democratic politics would be a good candidate for ethnocracy.

\section{References}

Agarin, T. 2005, 'Zugehörigkeit trotz exklusion: anerkennung zwischen den minderheiten und mehrheiten im post-Sowjetischen Baltikum', in DGO/Europäische Akademie Berlin (ed.), Integration Und Ausgrenzung Im Osten Europas, Forschungsstelle Osteuropa, Bremen, pp. 98-101.

2009 'Cooptation as integration? National programme "Integration of Society in Latvia” on minority participation', in Agarin, T. and Brosig, M. (eds.), Minority Integration in Central Eastern Europe; Between Ethnic Diversity and Equality, Rodopi, Amsterdam, pp. 199-223.

2010, A Cat's Lick: Democratisation and Minority Communities in the Post-Soviet Baltic. Rodopi, Amsterdam.

2013, 'Resident aliens? Explaining minority disaffection with democratic politics in the Baltic States', Ethnopolitics, vol. 12, no. 4, pp. 331-51. http://dx.doi.org/10.1080/17449057.2012.748247.

2014 'Travelling without moving? Limits of European governance for Romani inclusion’, Ethnicities, vol. 14, no. 6, pp. 737-55. http://dx.doi.org/10.1177/1468796814542184 .

2015, 'Nation-State building with the bear in mind: The impact of the Russian Federation in post-Soviet 'breakaway' regions', in Agarin, T. and Karolewski, I. (eds.) Extraterritorial Citizenship in Postcommunist Europe, Rowman \& Littlefield, Lanham, pp. 109-34.

2016, 'Estonia, Latvia, and Lithuania', The Wiley Blackwell Encyclopedia of Race, Ethnicity, and Nationalism, Wiley-Blackwell, http://dx.doi.org/10.1002/9781118663202

Agarin, T. and Cordell, K. 2016, Minority Rights and Minority Protection in Europe, Rowman \& Littlefield, Lanham.

Antane, A. and Tsilevich, B. 1999, 'Nation-Building and ethnic integration in Latvia', in Nation-Building and Ethnic Integration in Post-Soviet Societies, Kolstø, P. (ed.), Westview Press, Boulder, CO, pp. 63-152.

Birka, I. 2016, 'Expressed attachment to Russia and social integration: the case of young Russian speakers in Latvia, 2004-2010', Journal of Baltic Studies, vol. 47, no. 2, pp. 219-38. http://dx.doi.org/10.1080/01629778.2015.1094743 .

Brosig, M. 2008, 'A plan for the future? The Estonian State Integration Programme 20002007', Journal on Ethnopolitics and Minority Issues in Europe, vol. 7, no. 2, pp. 1-19. http://www.ecmi.de/fileadmin/downloads/publications/JEMIE/2008/2-2008-Brosig.pdf

Budryte, D. 2005, Taming Nationalism? Political Community Building in the Post-Soviet Baltic States, Ashgate, Aldershot.

Cianetti, L. 2015, 'Integrating minorities in times of crisis: Issues of displacement in the Estonian and Latvian integration programs', Nationalism and Ethnic Politics, vol. 21, no.2, pp. 191-212. http://dx.doi.org/10.1080/13537113.2015.1032029 .

Cordell, K. ed. 1999, Ethnicity and Democratisation in the New Europe, Routledge, London. 
Demuth, A. 2000, 'Post-Soviet minorities on the fence: Ethnic Russians between Estonia, the Russian Federation, and the international community', in Agozino, B. (ed.), Theoretical and Methodological Issues in Migration Research: Interdisciplinary, Intergenerational and International Perspectives, Ashgate, Aldershot, pp. 227-243.

Dorodnova, J. 2000, 'EU concerns in Estonia and Latvia: Implications of enlargement for Russia’s behaviour toward the Russian-speaking minorities'. EUI Working Papers 40.

Duina, F. and Miani, C. 2015, 'Fitting in the Baltics: national identity, minorities and compliance with EU accession requirements in Lithuania and Latvia', Comparative European Politics, vol.13, no. 5, pp. 535-52. http://dx.doi.org/10.1057/cep.2014.5

Ehin, P. and Berg, E. 2013, Identity and Foreign Policy: Baltic-Russian Relations and European Integration, Ashgate, Aldershot.

Galbreath, D. 2005, Nation-Building and Minority Politics in Post-Socialist States: Interests, Influence and Identities in Estonia and Latvia, Ibidem Verlag, Stuttgart.

Galbreath, D. and Galvin, M. 2005, 'The titularization of Latvian secondary schools: The historical legacy of Soviet policy implementation', Journal of Baltic Studies, vol. 36, no. 4, pp. 449-66. doi: https://doi.org/10.1080/01629770500000201

Hajda, L. and Beissinger, M. 1990, The Nationalities Factor in Soviet Politics and Society. Westview Press, Boulder, CO.

Hanovs, D. 2016, 'Can postcolonial theory help explain Latvian politics of integration? Reflections on contemporary Latvia as a postcolonial society'. Journal of Baltic Studies, vol. 47, no. 1, pp. 133-53. http://dx.doi.org/10.1080/01629778.2015.1103513 .

Herd, G. and Lofgren, J. 2001, “"Societal Security”, the Baltic States and EU Integration', Cooperation and Conflict, vol. 36, no. 3, pp. 273-96. doi: https://doi.org/10.1177/00108360121962425

Ijabs, I. 2016, 'After the Referendum militant democracy and nation-building in Latvia', East European Politics \& Societies, vol. 30, no. 2, pp. 288-314. http://dx.doi.org/10.1177/0888325415593630.

Jackson-Preece, J. 1997, 'National minority rights vs. state sovereignty: Changing norms in international relations?', Nations and Nationalism, vol. 3, no.3, pp. 345-364. http://dx.doi.org/10.1111/j.1354-5078.1997.00345.x

Järve, P.. 2000. 'Ethnic Democracy and Estonia: Application of Smooha’s Model.’ ECMI Working Paper 7. Available at: http://www.ecmi.de/uploads/tx_lfpubdb/working_paper_7.pdf

Keating, M. 2004, Plurinational Democracy: Stateless Nations in a Post-Sovereignty Era, Oxford University Press, Oxford.

Kochenov, D. and Dimitrovs, A. 2016, ‘EU Citizenship for Latvian 'Non-Citizens’: A concrete proposal', Houston Journal of International Law, vol.38, no.1

Kruusvall, J. 2002, 'Social perception and individual resources of the integration process', in in Lauristin, M. and Heidmets, M. (eds.), The Challenge of the Russian Minority: Emerging Multicultural Democracy in Estonia, Tartu University Press, Tartu, pp. 117162.

Malloy, Tove H. 2005, National Minority Rights in Europe, Oxford University Press, Oxford. doi: https://doi.org/10.1093/acprof:oso/9780199274437.001.0001

2009, 'Social cohesion Estonian style: Minority integration through constitutionalised hegemony and fictive pluralism', in Agarin, T. and Brosig, M. (eds.), Minority Integration in Central Eastern Europe. Between Ethnic Diversity and Equality, Rodopi, Amsterdam, pp. 225-54.

McGarry, A. and Agarin, T. 2014, 'Unpacking the Roma participation puzzle: Presence, voice and influence', Journal of Ethnic and Migration Studies, vol. 40, no. 12, pp. 1972-90. http://dx.doi.org/10.1080/1369183X.2014.897599 . 
Mertelsmann, O. 2003, The Sovietization of the Baltic States, 1940-1956, Kleio, Tartu.

Mikkel, E., and Pridham, G. 2005, 'Clinching the” Return to Europe”: The Referendum on EU accession in Estonia and Latvia', in: Szczerbiak, A. and Taggart, P. (eds.) EU Enlargement and Referendums, Routledge,London, pp. 160 - 192160.

Muiznieks, N. ed. 2010, How Integrated Is Latvian Society? An Audit of Achievements, Failures and Challenges, University of Latvia Press, Riga.

Nakai, R. 2014, 'Influence of party competition on minority politics: A comparison of Latvia and Estonia, Journal on Ethnopolitics and Minority Issues in Europe, vol. 13, no. 1, pp. 57-85. http://www.ecmi.de/fileadmin/downloads/publications/JEMIE/2014/Nakai.pdf

Petsinis, V. 2016, 'Ethnic relations, the EU, and geopolitical implications: The cases of Estonia and Croatia', Ethnopolitics, vol. 15, no. 2, pp. 230-44. http://dx.doi.org/10.1080/17449057.2015.1017317.

Pettai, V. 2005, 'Understanding Politics in Estonia: The Limits of Tutelary Transition.' Demstar Research Report, no. 25.

Phillips, A. 2007, Multiculturalism without Culture, Princeton University Press, Princeton.

Purs, A. 2012, Baltic Facades: Estonia, Latvia and Lithuania since 1945, Reaktion Books, London.

Reuters 2016, 'Burkini ban defended as French mayors urged to cool local tensions', The Guardian, August 16, sec. World news. https://www.theguardian.com/world/2016/aug/16/burkini-ban-defended-as-frenchmayors-urged-to-cool-local-tensions .

Silova, I. 2006, From Sites of Occupation to Symbols of Multiculturalism. Reconceptualizing Minority Education in Post-Soviet Latvia, Information Age Publishing, Greenwich, CT.

Smith, D. 2002, 'Framing the national question in Central and Eastern Europe: A quadratic nexus?’ The Global Review of Ethnopolitics, vol. 2, no. 1, pp. 3-16. doi: https://doi.org/10.1080/14718800208405119

Smith, G. 1996, ed. The Nationalities Question in the Post-Soviet States, $2^{\text {nd }}$. ed. Longman, New York.

Smooha, S. and Järve, P. 2005, The Fate of Ethnic Democracy in Post-Communist Europe, Local Government and Public Service Reform Initiative, Open Society Institute, Budapest. Available at: http://www.policy.hu/bieber/Publications/2005\%20Serbia\%20Smooha.pdf

Van Elsuwege, P. 2008, From Soviet Republics to EU Member States. A Legal and Political Assessment of the Baltic States' Accession to the EU, Martinus Nijhoff, Leiden. doi: https://doi.org/10.1163/ej.9789004169456.i-585

Vetik, R. and Helemäe, J. eds. 2011, The Russian second generation in Tallinn and KohtlaJärve : The TIES Study in Estonia, Amsterdam University Press, Amsterdam. http://www.tiesproject.eu/component/option,com_docman/task,doc_download/gid,351/ Itemid,142/index.html.pdf

Yiftachel, O. 1998, 'Planning and social control: Exploring the dark side', Journal of Planning Literature, vol. 12, no. 4, pp. 395-406. doi: https://doi.org/10.1177/088541229801200401

2006, Ethnocracy: Land and Identity Politics in Israel/Palestine, University of Pennsylvania Press, Philadelphia.

\section{Statement of Conflict of Interest}

The author is not aware of any conflicts of interest resulting from the publication of this text.

\section{Funding}

This paper was produced without funding. 